it is stated that information has been received that treasure in gold and precious stones "worth millions" has been discovered in a sealed tomb in the course of excavation, under the direction of Don Alfonso Caso, at Monte Alban, near Oaxaca. The bodies of ten Mixtec caciques were found buried under a heap of cups, urns, vases, and jars of jade, onyx, and crystal, together with personal ornaments and utensils of gold richly inlaid with turquoise. The skulls of the chieftains were encrusted with turquoise, and with them was a finely wrought mask of gold. The disorder of the funerary offerings suggests haste ; and this might have been due to the fact that the interment lies in the country of the Zapotec, with whom the Mixtec, notwithstanding their probable affinity, were frequently at war.

THE richness of the funerary offerings found at Monte Alban is fully in accord with the account given by Balboa, an early writer on the inhabitants of Mexico, of an interment in a cave-the usual type of burial chamber among the Mixtec-situated at Chalcotonga, supposed to be the gate of Paradise, in which the dead were laid out in rich garments and a number of small idols of gold, stone, and wood were placed in niches in the walls of the cave. Primary interments such as the recent discovery are supposed to have been confined to persons of high rank, the lower orders being placed in the ground for a time and their bones then collected and placed in a vase for deposit in a cave. It is suggested that the date of the burial is the fifteenth or early sixteenth century. Notwithstanding the scanty details, it is evident that this is the most imposing discovery of relics of the pre-Columbian culture of Mexico yet made. Its interest is considerably enhanced by the fact that so little relating to the Mixtec, who may in part have been of pre-Aztec strain, had been discovered previously.

\section{Electrical Measuring Instruments}

A SPECIAI exhibition of electrical measuring instruments opens at the Science Museum, South Kensington, on Feb. 13, and will remain on view until the middle of May. The exhibition illustrates the evolution of electrical measuring instruments, from the discovery of the fundamental principles on which they are based, up to the present day, and is substantially the same as the exhibition arranged by the British Electrical and Allied Manufacturers' Association and shown on the occasion of the Faraday Centenary Exhibition at the Albert Hall in September last. With the view of interesting the non-technical public, a series of simple demonstration experiments has been arranged to illustrate the various fundamental principles and their application to electrical measurement. Demonstrations will be given daily, the apparatus in some cases being a replica of that used by the original discoverer of the principle. The exhibition, which comprises about 250 exhibits, includes many original instruments, such as Kelvin's reflecting galvanometer, a resistance coil used by Wheatstone, Joule's current balance, and the coil with which Maxwell determined the ohm. Among the interesting replicas are those of Orsted's Compass, with which the magnetic effect of an electric current was first demonstrated, Ampère's electrodynamic apparatus, the apparatus with which Ohm discovered 'Ohm's Law', and Sturgeon's electromagnetic engine, which was the first machine to ernbody a commutator.

\section{Weights and Linear Measures}

IN addition, a small exhibition of weighing and linear measuring instruments will be on view in the Main Entrance Hall of the Science Museum from February until May. The exhibition illustrates briefly, by objects and photographic transparencies, progress in metrology since early times. In the very limited space available, only one form of balance has been selected for illustration--the precision or equal-armed balance; similarly, only standard scales and micrometer development have been shown in the linear section. The exhibits include, however, the principal British Exchequer standard weights and linear measures from the time of Henry VII. (1485), excepting, of course, the current national standards. This collection, hitherto in charge of the Standards Department of the Board of Trade, has now been transferred to the Science Museum.

\section{World's Commercial Electricity Supply}

Thanks to the activities of the World Power Conference, data in connexion with the supply of electricity throughout the world are now available. It appears that in 1930 the total capacity of the electric generators used was 114 million kilowatts and that the electric units (kw.h.) generated were 304,000 million. The electricity supply industry represents the largest public utility service in the world, and the capital invested in it almost equals the capital invested in railways. If we take as our unit a 1000 million $\mathrm{kw} . \mathrm{h}$., the total output of electricity in North America was 139, of which the United States generated 121, about two-fifths of the total world output. Germany comes next with an output of 29.4, Canada with 17.8, Great Britain with 17.2, Japan with $16 \cdot 3$, France with $15 \cdot 9$, and Italy with 10.8. Owing to the world-wide industrial depression, there is a distinct slowing down of the rate of development during this period as compared with the preceding year. This is mainly due to slackness in the industralised countries of western Europe and North America. Statistics in connexion with the capacity of the dynamos installed raise the question of whether the generating equipment throughout the world has outrun the demands made on it. It is a little difficult to answer this question, but we think that when industry revives there will be an immediate demand for more electrical machines.

\section{Northumbrian Coals}

The Fuel Research Board has just issued Paper No. 21 of the Physical and Chemical Survey of the National Coal Resources, being a report on the Yard Seam of Northumberland. The report is a very full one, and appears to be very carefully done. There is only one point to which attention may be directed. In places there is a narrow band of dirty coal at the top of the seam known locally as 'top brat', which the report states is "sometimes known as " roof coal" 
or "ramble"". From the wording of the report the reader might suppose that the term 'ramble' is confined to this particular coal, but as a matter of fact it is a genoric term for any thin bed of shaly matter that comes down when the underlying coal is worked. Thus in the "Glossary of Terms used in the Coal Trade of Northumberland and Durham ", by G. C. Greenwell, the first edition, published in 1849, defines ramble as "A thin stratum of shale, often found lying immediately above the seam of coal. It falls down, and, getting mixed with the coals, causes some trouble to the hewer, in getting it separated and cast back." Seeing that this brat, although described as dirty coal, is stated to have contained in one place as much as 69 per cent of ash, whereas one of the bands of shale contains only 46 per cent, it is obvious that this band might fairly come within Greenwell's definition. Perhaps the most interesting statement in the roport is that the authors find "the coking properties of the seam to be weak, but not nonexistent"; seeing that Northumbrian coals are generally supposed to be non-coking, this statement is a very important one, and leads to the inference that the Yard Seam smalls may be useful for blending with more strongly coking coals in order to produce a good metallurgical coke.

\section{Cormorant Fishing in China}

IT is sometimes said that since the neolithic age man has made no progress in domesticating wild creatures, oxcept for the improvements made in the breeds of animals domesticated at that time. But the domestication of the cormorant in China belongs to a much more recent period. The story has been worked out in detail by Berthold Laufer of the Field Museum of Natural History, Chicago (Field Museum Publication 300, Anthropological Series, vol. 18, 1931). The earliest mention of the use of trained cormorants for fishing refers to Japan and dates from about A.D. 607, when, presumably, such use was unknown in China. Yet the trained cormorants of Japan are scarcely more domesticated than the English cormorants which James I. delighted to watch, and for whom he appointed a 'master of the royal cormorants'. In China the birds are completely domesticated, being bred and reared in captivity, so that they become perfectly submissive to their masters, whose commands they understand, and whom they obey with the readiness and docility of a dog. Characteristic of their domestication is the appearance amongst them of colour varieties, particularly of albinistic and pied individuals. Their eggs are always hatched by domestic fowls and not by the cormorant mother, and the young are fed on special foods until the period of their training for fishing begins, and this lasts for seven or eight months.

\section{Investigations of Isotopes in 1931}

IN the Berichte der deutschen chemischen Gesellschaft for January 1932 will be found a report by Prof. O. Hahn upon the progress made during the year 1931 in the investigation of isotopic forms of the elements. In a footnote it is explained that the German Chemical Society has arranged for the continuation of such reports upon this subject until such time as an international commission shall have been set up for the purpose. The present report supplements the last biennial report, published in London nearly a year ago in the Annual Reports of the Chemical Society. After referring to the now determination by Mecke and Childs of the relative proportions in oxygen of its isotopes, and to the desirability of retaining oxygen for the present as the standard in estimating atomic weights in spite of its complex nature, the author of the report reviews the latest developments obtained by moans of the mass-spectrograph and of band spectra. Two useful tables are appended, containing respectively a list of sixty-three elements, which have hitherto been examined, together with their isotopes, and a list of no fewer than thirty-six pairs of isobars of nonradioactive elements.

\section{American Geophysical Union}

THE Transactions of the American Geophysical Union (published by the National Research Council) at its twelfth annual meeting, on April 30-May 1, 1931, appeared in June. This promptness, due to the able organisation of the secretary, Dr. J. A. Fleming, and to the use of direct reproduction from typescript, much enhances the value of the report. From its 227 pages geophysicists elsewhere can obtain a rapid and comprehonsive view of the large amount of work in this field now being done in the United States and, to a certain extent, in Canada and Mexico. The general assembly was mainly devoted to a symposium on time-signals; most of the work of the meeting is done in the seven sectional meetings. In seismology, the papers related chiefly to the development of new or improved instruments; in meteorology, to the work of the International Polar Year ; in terrestrial magnetism and electricity, including radio work, the papers were very numerous and covered a wide range of subjects ; in oceanography, the reports of many institutions on their past work were the main subject of discussion; hydrology forms a separate section, and had a long and varied programme; and there were a few papers on volcanology.

\section{Apparatus for Absorption Spectrophotometry}

Messes. Adam Hilger, Ltd., have published an interesting booklet dealing with the outfits they supply for absorption spectrophotometry in the visible and ultra-violet regions. The most important new instrument which is described is a form of ultra-violet spectrophotometer, working on the principle of the variation of the aperture of the beam, for which the name Spekker has been registered. This has been designed primarily for use with Hilger's medium quartz spectrographs, but may be attached to any similar instrument of sufficiently great aperture. Judging by the description of the instrument, and by a specimen set of absorption photographs for benzene in hexane, this should be both highly convenient to use and accurate in the results it yields. A photoelectric outfit is also described, although not very enthusiastically, the opinion being expressed that the use of a photoelectric cell in place of the eye or a photographic record diminishes the likelihood of a number of important sources of error being recognised, so that

$$
\text { No. 3250, VoL. 129] }
$$

